\title{
Die diens van die Gereformeerde predikant
}

\author{
J.M. Vorster \\ Departement Dogmatologie/Ekklesiologie \\ Potchefstroomse Universiteit vir CHO \\ POTCHEFSTROOM
}

\begin{abstract}
The ministry of the Reformed minister

This research article focuses on the traditional view and pattern of ministry as practised in the Reformed Churches in South Africa. The relevant ecclesiastical documents in this regard are studied. This investigation reveals a three-fold definition of the task of the ministry namely, the ministry of the Word of God and the sacraments, the leading in prayer in the midst of the congregation, and the supervision of the congregation and its fellow office-bearers. This three-fold definition is evalwated in view of Ephesians $4: 11-12$ and the complaint in ecclesiological circles that Reformed ministry tends to be institutionalist and clericalist. The whole issue of equipping believers as part of the task of the minister and the development of "enabling ministry" in these circles is discussed. An appeal is made for more research on practical ways in which the task of equipment can be realised effectively in Reformed circles.
\end{abstract}

\section{Inleiding}

In die teenswoordige gereformeerde ekklesiologiese besinning word tans deeglik besin oor die aard, gesag en rolvervulling van die besondere dienste in die gemeente. Hierdie nuwe besinning is die gevolg van die toenemende invloed van die gemeentebouteologie en die kerkgroeibeweging waarin gesoek word na 'n nuwe rolbeskrywing van die dienste ten einde 'n modern-funksionele diensvervulling daar te stel.

In hierdie proses word die diens van die predikant ook krities in oënskou geneem. Calian (1982:26) sê dat die predikant in die gereformeerde tradisie die rol van 'n "teacher-preacher" speel en dat hierdie rolvervulling in die praktyk gelei het tot die ontstaan van 'n lekekerk wat in beginsel nie veel verskil van die institusionalisme en klerikalisme in die Rooms-Katolieke kerk nie. Hy wys hier inderdaad op 'n belangrike punt. Van hierdie institusionalisme gee Dulles (1987: 37) 'n deeglike omskrywing. Ten opsigte van die verskil tussen die RoomsKatolieke en Protestantse beskouing in hierdie verband, maak Gibbs (1982:210) die volgende veelseggende stelling: "The priest moved from the altar to the pulpit, but the people remained undisturbed in their pews." 
Dieselfde kritiek word uitgespreek in die kringe van die gemeentebouteologie in Suid-Afrika waar op voetspoor van die bekende standpunt van Hendriks (1986:72 en 1992:21) gepraat word van die herder-kudde-model van bediening. Hiermee word bedoel dat in die gereformeerde tradisie die predikant se bediening sentraal staan en die gemeente hoofsaaklik passief bly. Stevens en Collins (1993:XII) se beskrywing van die gelowiges in gevestigde kerke as "God's frozen people" is ook in hierdie opsig van toepassing. Gereformeerde kerke het die vorm begin aanneem van "predikantekerke" of "dominokratiese" kerke waarin die diens van die predikant alle ander aktiwiteite domineer en selfs verdring. Dominokrasie het een van die knelpunte in die gereformeerde Ekklesiologie geword.

Die klag van ' $n$ predikantekerk of dominokrasie in die gereformeerde tradisie is nie 'n nuwe saak nie. In 1959 het Kamphuis (1959:4) reeds gewys op die klag van dominokrasie en die bedreiging van predikanteheerskappy. In 1982 het Trimp (1982:4) ook daarop gewys dat die gereformeerde praktyk van die diens van die predikant die klag van verstarring in die bediening ontlok. Die verstarring is die gevolg van ' $n$ bedieningspraktyk waarin alles in die gemeente wentel rondom die predikant. In Suid-Afrika het Louw (1984:66) gewys op die standpunt van Boon wat gesê het dat die gereformeerde ampsbeskouing vanweë die beklemtoning van die diens van die predikant eerder episkopaals as presbiteriaal is. Uit al hierdie beskouings blyk dit dat die diens van die gereformeerde predikant vanweë sy prominente plek in die bediening tans krities bejeën word. Vanweë die neiging tot 'n predikantekerk het die diens onder verdenking gekom. Hierdie klag word ook gedra deur die sosiologiese tendens van demokratisering in die moderne samelewing en in die kerk soos dit op uitvoerige wyse deur onderskeidelik Toffler (1990:10) en Anderson (1992:54) aangetoon word.

In die lig van die bevraagtekening van die teenswoordige dienspraktyk van die Gereformeerde predikant is dit nodig om weer te kyk na die beginselraamwerk waarbinne die diens van die predikant omskryf word. In hierdie artikel word teen die agtergrond van die klag van dominokrasie spesifiek aandag gegee aan die omskrywing van die roeping en diens van die predikant in die Gereformeerde Kerke in Suid-Afrika soos die tema na vore kom in die Belydenis, die Kerkorde, die Beroepsbrief en die Bevestigingsformulier. Die vraag wat behandel word, is of hierdie dokumente volledig uitdrukking gee aan wat die diens van die predikant behels en of dit vandag nog rigtinggewend is. Hierop word vervolgens ingegaan.

\section{Die diensomskrywing van die predikant}

\subsection{Die gereformeerde belydenis}

Oor die omskrywing van die roeping van die predikant sê die Nederlandse Geloofsbelydenis (NGB) die volgende: 
Ons glo dat hierdie ware kerk ooreenkomstig die geestelike bestuurswyse wat ons Here in sy Woord geleer het, geregeer moet word. Daar moet naamlik dienaars of herders wees om die Woord van God te verkondig en die sakramente te bedien ... (GKSA, 1979:509).

Die noodsaaklikheid van die diens van die predikant word in artikel 31 van die NGB behandel en aandag word gegee aan die roeping van die predikant, die wyse waarop beroeping moet plaasvind en die belangrike beginsels dat die predikante een en dieselfde gesag het omdat hulle almal dienaars van Jesus Christus is. Verder word die dienswerk nie uitgespel nie. Om egter vas te stel wat die NGB bedoel, is dit nodig om te let op wat Calvyn in hierdie verband gesê het omdat Guido de Bres, die opsteller van die NGB, op wesentlike punte in hierdie verband deur Calvyn beïnvloed is. Hy het die Confessio Belgica (NGB) opgestel in navolging van die Galliese konfessie wat vir 'n groot deel die ontwerp van Calvyn gevolg het (De Klerk, 1954:47; Aland, 1986:21; Jonker, 1994:78; Van Genderen, 1996:144). In die navorsing oor Calvyn se beskouing moet twee sake egter in gedagte gehou word. Die eerste is dat hy op sy beurt weer in hierdie verband beïnvloed is deur Bucer (Van't Spijker, 1988:123). Tweedens is daar verskillende interpretasies van die beskouing van Calvyn soos Van Itterzon (1974:79) en Rossouw (1988:135) tereg aangetoon het.

Oor die ampte in die algemeen het Calvyn (1949:54) gesê dat die Here sy kerk regeer en bestuur deur middel van mense, maar dat dit nie beteken dat Hy sy reg en eer oordra nie. Hy praat deur die mond van mense. So is die diens van mense die vernaamste senu waardeur die gelowiges in een liggaam verbind is. In sy uiteensetting van die ampte lê Calvyn (1949:58) baie klem op Efesiërs 4:11-12 en sê dat die apostels, profete en evangeliste "opgewek is aan die begin van God se ryk". Hy kan hulle egter ook nou en dan weer opwek volgens die noodsaaklikheid van die tyd. So 'n opwekking het volgens Calvyn (1949:59) in sy eie tyd (dit wil sê in die branding van die Reformasie - JMV) plaasgevind. In 'n goed ingerigte kerk het hierdie ampte egter geen plek nie. Die herders en leraars waarvan Efesiërs 4:12 praat, moet egter gesien word as die blywende en gewone ampte in die kerk. Hoewel Calvyn nie die voorkoms van die apostels en evangeliste van tyd tot tyd in die geskiedenis heeltemal afwys nie, is dit tog 'n vraag waarom hy, en die gereformeerdes na hom, so maklik afstand doen van die verskeidenheid dienste waaroor in die Skrifgedeelte geskrywe word. Hoekom verval evangeliste en bly die herders en leraars voortbestaan? Hierop word nie 'n duidelike antwoord gegee nie. In sy verdere beskrywing van die herders en leraars sê hy dat die leraars gemoeid is met die uitlê van die Skrif. Hulle het nie te doen met die bediening van die Woord en Sakramente nie. Die herders moet die evangelie verkondig en die sakramente bedien. Die leraar se taak is volgens die "gelykenis" van die profeet en dié van die herder volgens dié van die apostel. 
Voorts sê Calvyn (1949:63) dat die woorde opsieners, ouderlinge, herders en dienaars sonder onderskeid gebruik word omdat almal die diens van die Woord waarneem. Naas hierdie begrippe kom die begrippe oudstes en diakens voor. Eersgenoemde het die taak van toesighouding en laasgenoemde die taak van versorging. By die uitdeling van die materiële middele is die weduwees ook betrek. Hierdie twee ampte is egter nie ter sprake by Efesiërs 4:12 nie. 'n Belangrike punt by Calvyn in sy verklaring van die teks is die beklemtoning van die leraar wat spesifiek die Woord moet onderrig. Hoewel dit nie so duidelik is of hy werklik hiermee 'n vierde amp bepleit nie, is dit duidelik dat die onderrigtende uitleg van die Woord in die kerk 'n belangrike plek moet kry. Die NGB het hom nie hierin nagevolg nie maar die taak van die herder en leraar saamgevat in Woordverkondiging en sakamentsbediening. Waarskynlik is onderrig by Woordverkondiging ingesluit.

Die NGB gee dus nie 'n gedetailleerde uiteensetting van die diens van die predikant nie - slegs 'n samevatting van die roeping en die beginsels van die diens word kortliks gestel. Teen die agtergrond van die Rooms-Katolieke klerikalisme en die Anabaptisiese negering van die amp was die uiteensetting egter veelseggend. Die doel van 'n belydenis is ook om beginsels uit te spel en om nie volledig inhoud te gee aan kerkregering nie. Hierin het die NGB goed geslaag en is die beskrywing van die diens van die predikant in artikels 30 en 31 steeds gepas en van prinsipiële belang. 'n Verdere uiteensetting moet gegee word in 'n kerkorde. Daarom handel die Kerkorde van die Gereformeerde Kerke in Suid-Afrika uitvoerig oor die diens van die predikant soos in die volgende uiteensetting aangetoon word.

\subsection{Die Kerkorde van die Gereformeerde Kerke in Suid-Afrika}

Die Kerkorde van die Gereformeerde Kerke in Suid-Afrika handel in artikels 220 oor al die aspekte van die diens van die predikant (GKSA, 1979:14). Daar word gehandel oor die toelating (arts. 2-5), toesig oor (arts. 6-10), versorging (art. 11 en 20), uitdienstreding (arts. 12-14), taak (art. 16), gelykheid in status (art. 17 en 84), die dienswerk van professore (art. 18) en die taak van die kerke ten opsigte van die voorsiening van voomemende predikante. Artikel 16, wat spesifiek handel oor die diens van die predikant lui soos volg:

Die amp van die bedienaars van die Woord is om in die gebede en bediening van die Woord te volhard, die sakramente te bedien, om goed ag te gee op hulle medebroeders, op die ouderlinge, op die diakens sowel as op die gemeente, en eindelik om saam met die ouderlinge die kerklike dissipline uit te oefen en te sorg dat alles betaamlik en ordelik plaasvind (GKSA, 1979:17). 
In hierdie artikel word dus klem gelê op die diens van die gebede, die bediening van Woord en sakramente, die ag gee op medebroeders en die gemeente, die toepassing van die kerklike tug saam met die ouderlinge en die toesig oor orde in die gemeente. Om die praktyk van die diens van die predikant soos dit gestalte gevind het in die bediening in die Gereformeerde Kerke in Suid-Afrika te begryp, moet gelet word op die invloed van die verklarings van die Kerkorde wat oor die jare in die kringe van Gereformeerde kerke gegeld het. Veral moet gelet word op die ontwikkelinge in die Gereformeerde Kerken in Nederland en verbandhoudende tradisies.

Jansen (1923:70) het in sy verklaring van die artikel die werk van die predikant saamgevat in drie aspekte naamlik, die diens van die Woord, die diens van die sakramente en die regering van die kerk. Hy het hom dus in breë trekke gehou by die omskrywing van die NGB en nie die detail uitgespel nie. Voorts het hy ook nie die die begrip amp, die fundering daarvan en die hoeveelheid ampte bevraagteken nie. Hoewel hy 'n goeie samevatting gee van wat die amp behels, het sy werk het nie verdere kritiese nadenke gestimuleer nie.

Bouwman (1970:328) het meer uitvoerig geskrywe. Hy het gesê dat die amp deur Christus ingestel is om die gemeente te vergader, te regeer en te versorg. 'n Belangrike punt wat hy beklemtoon het, is dat die amp eintlik gesien moet word as diens en hiervoor beroep hy hom op 1 Korintiërs 3:6-9. Die ampsdraers is eintlik dienaars. Hy sê ook dat die locus classicus vir die instelling gevind word in Efesiërs 4:11-12. Sonder beredenering sê hy, soos Calvyn, dat die buitengewone gawes waarvan in die Skrifgedeelte sprake is, terugtree en dat die apostelamp divergeer in die predikant, ouderling en diaken. Hierdie standpunt van Calvyn en Bouwman word steeds, sonder beredenering, op 'n wye vlak nagevolg in die gereformeerde tradisie in Suid-Afrika (vgl. Kleynhans, 1982:24).

Teenoor die Independentisme het Bouwman die noodsaaklikheid van die amp verdedig. Hy vat die saak verder soos volg saam:

De H Schrift leert ons duidelijk, dat de Heere het ambt heeft ingesteld, om zijne gemeente te vergaderen, te regeeren en te verzorgen. De apostelen beroepen zich op hunne zending van Godswege, en ontleenen aan hun roeping macht en autoriteit. Zij zijn dienaren van Christus (Rom. 1:1; Gal. 1:10; Col. 1:7), gezanten van Christus (2 Cor. 5:20), die het evangelie, dat hun is toevertrouwd, verkondigen (1 Cor. 4:1). Ook de gewone ambten zijn door Christus gegeven (Ef. 4:11; 1 Cor.12:5, 28). Van de ouderlingen in Efeze wordt gezegd, dat zij door den Geest tot opzieners der kudde zijn aangesteld (Hand. 20:28). Al is het dan ook zoo, dat al de geloovigen zijn geroepen, om als profeten, priesters en koningen den Heeren te dienen, de Heere heeft voor de leiding en verzorging der gemeente, voor de prediking des evangelies en voor het betoon der barmhartigheid bijzondere diensten gegeven, met een bijzondere zending en opdracht (Bouwman, 1970:345). 
'n Baie belangrike bydrae van Bouwman in sy beredenering van die ampte is die klem wat hy lê op die amp van die gelowige (Bouwman, 1970:331). Vir hom is daar ' $n$ noue band tussen dié amp en die amp van die gelowige. Die gelowige moet ook die Woord uitdra. Hy erken selfs die reg van die gelowige om te leer (potestas dogmatica-1 Kor. 11:4, 5; Rom. 15:14; 1 Tess. 5:11, 14), te regeer (potestas ordinis et regiminis) en om reg te spreek (potestas jurisdictionis Hand. 1:15-26, 6:3-6, 14:23). Ongelukkig is die verreikende implikasies van hierdie standpunt nie in die gereformeerde tradisie verder ontgin en uitgewerk nie.

In sy verklaring van artikel 16 lê Bouwman (1970:485) ook klem op die amp as diens en sê dat dit die bedoeling van die artikel is om slegs die hoofsaak aan te dui. Die hoofsaak is dan die bediening van die Woord en die gebede; die bediening van die sakramente en die regering wat insluit die toepassing van die tug en die handhawing van die goeie orde. Sy siening van die diens van die predikant getuig van soepelheid en hy kan nie die klag van dominokrasie in die gereformeerde tradisie ten laste gelê word nie. Bouwman is waarskynlik die kerkregtelike wat die meeste invloed uitgeoefen het op denke in dié verband binne die Gereformeerde Kerke in Suid-Afrika.

Na die tydperk van Bouwman het die neiging in die Gereformeerde Kerken in Nederland ontstaan om die dienswerk vail die predikant meer te reglementeer. In 1959 is die kerkorde in daardie kring hersien. In die nuwe kerkorde is die taak van die predikant uitvoerig uiteengesit en word pertinent gewys op evangelisering, bediening van die Woord en sakramente, uitspreek van die seèn, leiding en amptelike werksaamhede in die gemeente soos die afneem van geloofsbelydenis, bekendmaking van die kerklike tug, bevestiging van ampsdraers, huweliksbevestigings, kategetiese onderrig, herderlike sorg, huisbesoek en ander besondere opdragte wat hy mag ontvang (Nauta, 1971:68). Dieselfde tendens het na vore gekom in die Christian Reformed Church in Noord-Amerika en ook daar is die diens van die predikant pertinent uitgespel. In hierdie kring word egter ook klem gelê op die "encouragement" van die gelowiges tot evangelisering (Monsma, 1967:60). Ook die Canadian Reformed Churches gee in hulle kerkorde 'n detailbeskrywing van die diens van die predikant (Van Oene, 1990: 78). In Suid-Afrika het die Nederduitse Gereformeerde Kerk ook dié weg opgegaan (NGK, 1990:3).

Hierdie ontwikkelinge is veelseggend, veral as daarop gelet word dat die klag van dominokrasie of predikantekerk toegeneem het met die moderne neiging in die gereformeerde tradisie om die diens van die predikant in kerkordes te reglementeer. Die soepelheid van Calvyn en Bouwman het verlore gegaan en daarmee saam die ewe belangrike beklemtoning van die diens van die gelowige in sy "amp" as gelowige. So het die instituutmodel van bediening in die gereformeerde bediening al hoe meer beslag gekry (vgl. Vorster, 1996:18). 
Kerkregtelikes binne die Gereformeerde Kerke in Suid-Afrika het onder invloed van Calvyn en Bouwman hulle tot nog toe daarvan weerhou om te pleit vir 'n gedetailleerde uiteensetting van die diens van die predikant in die Kerkorde. Kruger e.a. (1966:114) sê duidelik dat dit in artikel 16 net gaan oor die beginsels vir die bediening. In ooreenstemming hiermee sê Van der Linde (1983:70) dat dié artikel slegs die kern stel en dit is die drieërlei aspek van gebed, Woordbediening en toesig. Die belangrike is dat die Koningswoord in die kerk gehoor word. In sy uiteensetting lê hy veral klem op die gebedstaak van die predikant. Spoelstra (1989:112) beroep hom op Calvyn en sê dan ook dat artikel 16 net in breë trekke die diens van die predikant beskryf. Vir hom is die belangrike saak die Woorddiens wat die verdere uitoefening van die diens bepaal.

Met dié beskouinge is beweeg op 'n suiwer kerkregtelike weg. 'n Kerkorde behoort immers nie te reglementeer nie. By reglementering duik die vraag telkens op wat belangrik is en wat in so 'n reglementering weggelaat moet word. Wat weggelaat word, word dan ook minderwaardig geag in die bedieningspatroon wat op die bepaalde ordereëling gebou is. Reglementering yk ook vaste patrone en hierdie vaste rigiede bedieningspatrone laat min ruimte vir vernuwing in die opbou van die kerk. Om te waak teen dominokrasie moet dus wegbeweeg word van reglementering in die omskrywing van die diens van die predikant in die Kerkorde. Die noue verbintenis tussen die besondere diens en die diens van die gelowige moet vooropstaan. 'n Fyner omskrywing kan gedoen word in die beroepsbrief en bevestigingsformulier wat nie op dieselfde vlak lê as die Kerkorde nie. Om die diens van die Gereformeerde predikant te evalueer word hierdie dokumente vervolgens in meer besonderhede bespreek.

\subsection{Die beroepsbrief en die bevestigingsformulier}

\subsubsection{Die beroepsbrief}

Oor die inhoud van die diens van die predikant stel die konsepberoepsbrief wat binne die Gereformeerde Kerke in Suid-Afrika gebruik word die volgende:

Voorts vertrou die kerkraad dat hy (die beroepe predikant - JMV) spoedig tot die gemeente sal oorkom om deur leer en voorbeeld, bestuur en opsig, alles te doen wat ' $n$ herder en leraar betaam, ooreenkomstig Gods heilige Woord en die belydenisskrifte van die Gereformeerde Kerke wat daarop gegrond is; in besonder deur die verkondiging van die Evangelie en die bediening van die Heilige Doop en die Heilige Nagmaal op die tye in die gemeente vasgestel; deur besoek aan die gemeentelede aan hulle huise en deur onderwysing van die Bybelse en kerkgeskiedenis en van die geloofsleer van die gereformeerde godsdiens in katkisasie wat die hele jaar deur weekliks gehou moet word (GKSA, 1979:97). 
Hoewel hierdie voorbeeld slegs as 'n konsep voorgehou word, word dit in die praktyk feitlik deurgaans net so gebruik en gee die konsep nog 'n belangrike aanduiding van wat in die Gereformeerde Kerke in Suid-Afrika oor die diens van die predikant gebruiklik is. Deur leer en voorbeeld, bestuur en opsig moet die predikant dus sy diens verrig. Hy moet die Woord verkondig en die sakramente bedien en hy moet huisbesoek doen en die kategetiese onderrig waarneem. Hierdie aspekte raak die kern van sy diens. Ook hier word die diens van die predikant nie gereglementeer nie. 'n Kerkraad is egter by magte om 'n beroepsbrief so op te stel dat meer besonderhede daarin gestel kan word, byvoorbeeld as daar aan die beroepe predikant besondere take soos jeugsorg, evangelisering van buitekerklikes of ander pligte opgedra word. Sulke besondere take mag egter nie verskil met dit wat die Skrif en belydenis oor die roeping van die predikant sê nie. Hy kan dus nie beroep word om slegs gemeentelike administrasie te behartig of in 'n bepaalde klerklike hoedanigheid te dien soos in sommige kerklike tradisies die geval is nie. Hieroor moet die beroepsbrief duidelik wees. Sy dienswerk moet val binne die breë raamwerk van diens van die Woord en sakramente, gebede en toesig.

\subsubsection{Die bevestigingsformulier}

Die bevestigingsformulier gee 'n goeie oorsig van die diens van die predikant. Klem word hier ook gelê op Efesiërs 4:11-12 en die toerusting van die gelowiges word genoem maar meer word nie daaroor gesê nie (GKSA, 1992:620). Op hierdie saak sal later teruggekom word. Op grond van verskeie ander Skrifgedeeltes word gesê dat die kudde van die Here versorg, gelei en beskerm moet word. Die predikant moet die pligte uitvoer deur die Woordverkondiging, bediening van die sakramente, diens van die gebede en die uitoefening van sy regeertaak saam met die ouderlinge. In hierdie verband word verwys na Handelinge 20:28.

Verskeie Skrifgedeeltes word in hierdie formulier aan die orde gestel: Vir die diens van Woordverkondiging, erediens en huisbesoek word verwys na Titus 1:9; 2 Timoteus $2: 15$; 2 Timoteus $4: 1-2$; vir die bediening van die sakramente na Matteus 28:19; vir die voorbidding na 1 Timoteus 2:1; vir die onderrig aan die verbondskinders na Johannes 21:15 en vir toesig en tug na Matteus 16:19. Daarby word die verkondiging van die Evangelie aan "afgedwaaldes" genoem. Hieruit blyk dit dat in die gereformeerde tradisie ernstig gepoog is om die diens van die predikant te fundeer in relevante Bybelse beginsels. 'n Sosiologiese of bestuursmatige detailbeskrywing van die diens van die predikant is vreemd aan die gereformeerde tradisie soos die tradisie uitdrukking vind in die belydenis, kerkorde, beroepsbriewe en bevestigingsformulier. 


\subsection{Konklusie}

Uit die voorafgaande uiteensetting kan drie belangrike sake uitgelig word wat van belang is vir die verstaan van die diens van die Gereformeerde predikant en die vermyding van dominokrasie in hedendaagse bediening.

- Die diens van die predikant word in die verskillende kerklike dokumente nie in die fynste besonderhede uitgespel nie. Hoewel daar verskillende nuanseringe is, word gehou by die sogenaamde drieërlei taak van die predikant. Hierdie drieërlei taak is die bediening van die Woord en sakramente, die diens van die gebede en toesig oor die gemeente saam met die kerkraad. In die uitoefening van sy roeping moet die predikant hom hierby hou en daarop word hy gewys in sy beroepsbrief en die bevestigingsformulier. Hy kan hierdie drieërlei taak nie laat oorheers deur ander take wat uit die praktyk van die bediening op sy pad mag kom nie. Om die taak te verrig moet hy ook op een of ander manier aan 'n gemeente verbonde wees. Daar is een belangrike rede waarom artikel 16 van die Kerkorde en die ander dokumente wat daarop gegrond is, nie die diens van die predikant in die fynste besonderhede uitspel nie. Op hierdie wyse word reglementering en 'n rigiede hiërargiese beskouing van die diens vermy. Daarmee word verhoed dat dominokrasie intree en die organiese band en samehang van die besondere dienste en die diens van die gelowige versteur word. Hierdie beginsel is belangrik en behoort nie te verander nie, tensy uit die Skrif bewys kan word dat daar tot die drieërlei beskrywing van die diens van die predikant 'n saak bygevoeg moet word. Of die soepel benadering egter in die praktyk van Gereformeerde bediening altyd neerslag gevind het, is 'n ope vraag. Gereformeerde bediening dra, ten spyte daarvan, duidelike tekens van 'n predikantekerk.

- In die gereformeerde denke oor die besondere dienste is daar algaande wegbeweeg van die uitdrukking "amp" na die meer Bybelse uitdrukking "diens". Hoewel Trimp (1982:115) oordeel dat die begrip "amp" omvattender is, is die uitdrukking "diens" meer korrek in Bybelse sin. Barth (1955:787) sê tereg dat die begrip "diens" dui op aktiwiteit omdat dit in beginsel afgelei is van die diens van Christus. "Diens" loop, volgens hom, nie die gevaar van klerikalisme nie. Stott (1979:17) kom met verwysing na 1 Korintiërs 4:1 en 2 tot dieselfde gevolgtrekking.

Tog beteken die uitdrukking "diens" nie dat daar nie 'n bepaalde gesag aan die diens verbonde is nie. Diens beteken nie dat die besonderheid van die ampte verwater word of uitgerangeer word nie. Die kerk word nie 'n liggaamsmodel waarin die besondere dienste afgetakel word nie. Teen so 'n liggaamsmodel waarsku Erasmus en Kellerman (1995:604) tereg. Stott (1979:29) en Versteeg (1985:28) sê dat die diens gesag impliseer en dat 
daardie gesag lê in die bediening van die Woord. Louw (1984:57) toon ook aan dat die uitdrukking presbuteroi wys op 'n bepaalde ampswaardigheid. In hierdie verband sou dit beter wees om te praat van ' $n$ bepaalde "dienswaardigheid". Die beklemtoning van die amp as "diens" en die inkleding van die werk van die predikant in hierdie begrip sal ook meehelp om die probleem van dominokrasie waarin die element van sekulêre "hoër" gesag ingesluit is, te oorkom.

- Besonder min word egter in die tradisionele gereformeerde denke oor die diens van die predikant gemaak van die verhouding tussen besondere diens en die diens van die gelowige. Slegs Bouwman (1970:331) lê daarop besondere $\mathrm{klem}$. Op sy beskouing is reeds gewys. In die gereformeerde beskouing oor die diens van die predikant sedert Calvyn word baie, en tereg, gesteun op Efesiërs 4:11-12. In hierdie gedeelte sê Paulus dat die dienste gegee word "om die gelowiges toe te rus vir hulle diens en vir die opbou van die liggaam van Christus". Die 1953 Afrikaanse vertaling vertaal die gedeelte so: “... om die heiliges toe te rus vir hulle dienswerk tot opbou van die liggaam van Christus". Die NIV sê dieselfde met sy vertaling wat soos volg lui: “... to prepare God's people for works of service, so that the body of Christ may be built up ..."

Versteeg (1985:26) sê dat daar drie opvattings oor die gedeelte is. Die eerste opvatting gaan uit van die standpunt dat hier oor die drieërlei doel van die ampte gepraat word. Die eerste opvatting is dat die ampte die gelowiges moet toerus, diens moet betoon en die liggaam van Christus moet opbou. Die klem lê dus op die werk van die besondere amp. Die tweede opvatting is dat die doel van die dienste tweërlei is, naamlik dat die gelowiges toegerus moet word tot diensbetoon en die ampte self die gemeente moet opbou. Die derde opvatting is dat die amp net een doel het en dit is om die gelowiges toe te rus sodat hulle hulle diensbetoon kan verrig en op hierdie wyse die liggaam van Christus kan opbou. Versteeg (1985:26) kies, op grond van die verband wat hy sien tussen Efesiërs 4:12 en Efesiërs. 4:16 vir die laaste opvatting. Hiervoor maak hy 'n oortuigende saak uit. Die betekenis is duidelik: deur die dienswerk van die besondere dienste moet die gelowiges toegerus word om hulle diens te verrig sodat die gemeente opgebou kan word. Daar is dus 'n noue organiese verhouding tussen die diens van die besondere dienste, waaronder dus ook die diens van die predikant en die roeping van die gelowige. (Vgl. ook Versteeg, 1988:48.)

Hierdie band moet in die dienswerk van die predikant duidelik tot sy reg kom. Die diens van die predikant staan nie op meganiese wyse bo of langs die gelowiges as iets op sigself nie, maar funksioneer organies en dinamies in verhouding met die gelowige. Die dienswerk is primêr begeleidend en motiverend. 
Velema (1996:176) sê daarom tereg dat die vorming en toerusting van gelowiges in die midde van die gemeente moet plaasvind (vgl. ook Swanepoel, 1996:104). In die verlede is waarskynlik geoordeel dat hierdie vorming en toerusting plaasvind in die gewone gang van die predikant se uitoefening van sy diens, soos deur die bediening van die Woord en Sakramente, huisbesoek en die kategetiese onderrig. Die vraag is of hierdie tradisionele opvatting reg laat geskied aan die bedoeling van Efesiërs 4:11-12? Is die toerustingstaak van die predikant nie 'n taak wat pertinent by die drieërlei omskrywing van sy diens in die kerkorde, bevestigingsformulier en beroepsbrief gevoeg moet word nie? En in hoe 'n mate sal die toevoeging help om die bedreiging van dominokrasie, klerikalisme en gemeentelike onbetrokkenheid te oorkom? Hierdie saak moet verder ondersoek word en in die volgende paragrawe word meer aandag daaraan gegee.

\section{Die predikant as toeruster}

In hierdie gedeelte oor die betekenis van Efesiërs 4:11-12 word nie gehandel oor die hoeveelheid dienste wat uit die gedeelte afgelei kan word of oor die stelling dat sekere ampte teruggetrek het en ander van blywende betekenis vir die kerk is nie. Die tema is ' $n$ probleem op sy eie wat nog baie indringende navorsing nodig het. Hierop wys Louw (1984:59) tereg. Wel word spesifiek aandag gewy aan die opdrag tot toerusting van die gelowiges.

Die woord wat in Efesiërs 4:12 met toerus vertaal word, is katartismos en dit is die enigste plek waar die woord in die Nuwe Testament aangetref word. Calvyn (1854:280) sê dat katartismos daarop gerig is om die gelowige in gelid te kry met die hele liggaam. Nida en Louw (1989:680) sê dat die begrip beteken om iemand volledig op te lei sodat hy aan sy doel kan beantwoord. Rienecker (1980:530) lê ook klem op die "volledig oplei" en sê dat die woord in mediese sin verstaan moet word. Soos 'n gebreekte been gespalk moet word om hom weer bruikbaar te maak vir die liggaam en dit in harmonie te bring met die ander ledemate, so moet die gelowige deur opleiding gebring word tot diensbaarheid in die liggaam van Christus. Maar wat behels die toerusting en opleiding?

Uit die gebruik van die woord en die betekenisse wat daaraan geheg word, is dit geregverdig om tot die konklusie te kom dat dit hier gaan om verstandelike onderrig. Deur onderrig moet die gelowiges geleer word om hulle funksie in diens van die gemeente te vervul. Om hierdie rede het Calvyn (1949:53) die amp van die leraar beklemtoon. Die leraar, anders as die herder, bedien nie die Woord en sakramente nie, maar lê die Woord uit. Hierdie onderrig is iets anders as Woordbediening in die breë. Woordbediening, en daarmee saam sakramentsbediening, is gerig op die wek, werk en versterk van die geloof. Toerus in Efesiërs 4:11-12 is gerig op die vermeerdering van kennis ten einde die gelowige vaardig te maak om sy diens te vervul. 
Die toerustingswerk van die predikant kan dus nie sonder meer onder die Woordverkondiging tuisgebring word, soos waarskynlik in die gereformeerde tradisie gebeur het nie. Dit is ook meer as die "educational ministry" waarvoor Adams (1980:272) pleit. Hierdie taak is 'n afsonderlike kategorie. Daar kan dus gesê word dat die dienswerk van die predikant naas die drieëlei beskrywing van sy roeping as Woorddiens, gebede en toesig, soos tradisioneel in die Gereformeerde belydenis, kerkorde, beroepsbrief en bevestigingsformulier gestel is, ook die belangrike element van toerusting deur onderrig moet bevat. As deel van die vervulling van sy taak, soos hierdie dokumente dit beskryf, moet die predikant dus deur onderrig die gelowiges toerus om deur hulle die gemeente as liggaam met baie gawes te laat funksioneer en op te bou (vgl. Williamson \& Clark, 1991:63; Velema, 1996:163).

Hierdie insig het verskeie implikasies vir die werk van die predikant. In die praktiese bediening beteken dit dat die gawes van die gelowiges (1 Kor. 12) geïdentifiseer moet word. Die predikant moet deur verstandelike onderrig op 'n geordende wyse, soos die geval is met die bediening van die Woord, die gawes ontwikkel en dit effektief in diens stel van die hele gemeente. Op dié wyse moet almal in die gemeente betrek word om onderrig te ontvang en diens te lewer. Gelowiges oor die wye spektrum van die gemeentelike lewe moet op dié wyse in die gesigsveld gebring word. Die hele struktuur van die gemeente verander van 'n "kom-struktuur" na 'n "gaan-struktuur" (Gibbs, 1993:231).

Die konkrete toepassing van die toerustingsrol van die predikant in sy organiese band met die gelowiges sal ook 'n effektiewe antwoord bied op die afbrekende gevolge van die instituutmodel met sy dominokrasie en klerikalisme. Op hierdie wyse aktiveer die predikant op konkrete en geordende wyse die hele gemeente tot roepingsvervulling en kerkgroei (Gibbs, 1992:209; Germond, 1995:173). Gelowiges word opgelei om as gelowiges binne die gemeente diens te lewer dienslewering soos die versorging van armes, siekes en beproefdes. Hulle, wat die gawes daarvoor van die Here ontvang het, word geleer om Bybelstudie te lei, mense te evangeliseer en voorbidding te doen. Ander word byvoorbeeld geleer hoe om te organiseer, te bestuur en te administreer. Die klem word geskuif van die predikant, om wie alle aktiwiteite in die hedendaagse Gereformeerde bediening dikwels draai, na die diens van die gelowige. Daar word in die kerk dan nie meer, soos in die instituutmodel met sy dominokratiese en klerikalistiese karakter, net gerus op die besondere dienste nie. Bediening word dan "enabling ministry" (Beckham, 1995:29; Vorster, 1996:123).

Die toerustingstaak van die predikant behoort, sonder om te reglementeer, ingeskryf te word by die drieërlei omskrywing van sy diens in die kerkorde, beroepsbrief en bevestigingsformulier. Hierdie aspek moet nie, soos in die verlede, slegs veronderstel word as deel van die taak van Woordverkondiging nie, 
omdat die saak, soos reeds aangedui is, volgens Efesiërs 4:12 'n beginsel is net soos die Woorddiens, gebede en toesig. So 'n pertinente beskrywing behoort die indruk te vestig dat die predikant nie primêr ' $n$ kerkhoof is wat met leierskap en bestuursvaardigheid sy taak uitvoer nie, maar 'n begeleidende dienskneg wat gelowiges toerus en motiveer tot dinamiese roepingsvervulling in die kerk en die samelewing.

Om die toerustingstaak van die predikant in die Gereformeerde Kerke in SuidAfrika dus volgens die gegewens van Efesiërs 4:11-12 tot sy reg te laat kom, sal ook gewerk moet word aan ' $n$ verandering aan die huidige algemene bedieningspatrone. Binne die predikant se huidige patroon van Woordverkondiging, sakramentsbediening, kategese, pastoraat en toesig moet 'n omvattende program van toerusting van gelowiges dus ook tot sy reg kom. Die vestiging van hierdie toerustingstaak binne die beginselraamwerk van die Gereformeerde bedieningsmodel is 'n tema waaroor verdere navorsing baie waardevol sal wees. Hierdie navorsing moet handel oor die wyses waarop die toerustingsaspek van die predikant se diens op effektiewe wyse binne die konteks van die hedendaagse gemeente gevestig kan word. Die gereformeerde Ekklesiologie sal hieraan dringend aandag moet gee.

\section{Bibliografie}

ADAMS, J.E. 1980. Shepherding God's flock. A handbook on pastoral ministry, counselling, and leadership. Grand Rapids : Zondervan.

ALAND, K. 1986. A history of Christianity. Philadelphia : Fortress Press.

ANDERSON, L. 1992. A church for the 21 st century. Minneapolis : Bethany House Publishers.

BARTH, K. 1955. Kirchliche Dogmatik. Die Lehre von der Versohnung. IV/2. Zurich : Evangelische Verlag.

BECKHAM, W.A. 1995. The Second Reformation: Reshaping the church for the twentyfirst century. Houston: Touch Publications.

BOUWMAN, H. 1970. Gereformeerd kerkrecht. Het recht der kerken in de practijk. Kampen : Kok.

CALIAN, C.S. 1982. Today's pastor in tomorrow's world. Philadelphia : The Westminster Press.

CALVYN, J. 1854. Commentary on the Epistles of Paul to the Galatians and Ephesians Edinburgh : Calvin Translation Society.

CALVYN, J. 1949. Institutie, of onderwijsing in de christelijke godsdienst. Delf : Meinema.

DE KLERK, P.J.S. 1954. Gereformeerde simboliek. Pretoria : Van Schaik.

DULLES, A. 1987. Models of the church. New York : Double Day. 
ERASMUS, L.M. \& KELLERMAN, J.S. 1995. Gemeentebou se liggaamsmodel: 'n Kerkbegrip van onder. Nederduitse Gereformeerde Teologiese Tydskrff, 36(4):604-616, Des.

GEREFORMEERDE KERKE IN SUID-AFRIKA. 1979. Kerkorde van die Gereformeerde Kerk in Suid-Afrika, soos gewysig deur verskillende sinodes. Potchefstroom : Admin. Buro van die Gereformeerde Kerk.

GEREFORMEERDE KERKE IN SUID-AFRIKA. 1992. Die berymde Psalms en Skrifberymings. Potchefstroom : Calvyn Jubileum Boekefonds.

GERMOND, G. 1995. Involvement of the laity. (In Buchanan, D. \& Hendriks, J. Meeting the future. Christian leadership in South Africa. Randburg : Knowledge Resources. p. 173-181.)

GKSA

$k y k$

GEREFORMEERDE KERKE IN SUID-AFRIKA

GIBBS, E. 1992. I believe in church growth. London : Hodder \& Stoughton.

GIBBS, E. 1993. Winning them back. Tackling the problem of nominal Christianity. Kent Monarch Publications.

HENDRIKS, J. 1986. Vernuwing in bedieningstruktuur. Nederduitse Gereformeerde Teologiese Tydskrif, 27(1):72-85, Januarie.

HENDRIKS, J. 1992. Strategiese beplanning in die gemeente. Die beginsels en praktyk van gemeentevernuwing. Wellington: Hugenote Uitgewers.

JANSEN, J. 1923. Korte verklaring van de Kerkordening. Kampen : Kok.

JONKER, W.D. 1994. Bevrydende waarheid. Die karakter van die gereformeerde belydenis. Wellington : Hugenote Uitgewers.

KAMPHUIS, J. 1959. Een fragment uit de strijd van dominocratie contra Dominocratie. Goes : Oosterbaan en Le Cointre.

KLEYNHANS, E.P.J. 1982. Gereformeerde kerkreg. Pretoria : NG Kerkboekhandel

KRUGER, L.S., e.a. 1966. Handleiding by die Kerkorde van die Gereformeerde Kerke in Suid-Afrika. Potchefstroom : Pro Rege.

LOUW, L.K. 1984. Dienswerk. 'n Eietydse bedieningsmodel vir die opbou van die gemeente. Pretoria : UNISA. (D.Th.-proefskrif.)

MONSMA, M. 1967. The new revised Church Order commentary. A brief explanation of the Church Order of the Christian Reformed Church. Grand Rapids : Zondervan Publishing House.

NAUTA, D. 1971. Verklaring van de Kerkorde van de Gereformeerde Kerken in Nederland. Kampen : Kok.

NEDERDUITSE GEREFORMEERDE KERK. 1990. Die Kerkorde van die Nederduitse Gereformeerde Kerk, met reglemente en besluite van kerkregtelike aard soos vasgestel deur die Algemene Sinode in Oktober 1990.

NIDA, E.A. \& Louw, J.P. 1989. Greek - English lexicon of the New Testament based on semantic domains. Kaapstad : Bybelgenootskap. 
NGK

$k y k$

NEDERDUITSE GEREFORMEERDE KERK

RJENECKER, F. 1980 Linguistic key to the Greek New Testament. Grand Rapids Zondervan Publishing House.

ROSSOUW, P.J. 1988 Aspekte van die ampsbeskouing by Calvyn (In Rossouw, P.J., red. Gereformeerde ampsbediening. Pretoria : NG Kerkboekhandel. p. 128-150.)

STEVENS, R.P. \& COLLINS, P. 1993. The equipping pastor. A systems approach to congregational leadership. New York : Alban Institute.

SPOELSTRA, B. 1989. Gereformeerde Kerkreg en Kerkregering: 'n Handboek by die Kerkorde. Hammanskraal : HTS.

STOTT, J.R.W. 1979. The preacher's portrait. Some New Testament studies. Grand Rapids : Eerdmans.

SWANEPOEL, A.C. 1996. Eietydse ampsbediening en bedieningstrukture vir ouderlinge en diakens in die Nederduitse Gereformeerde Kerk - 'n kerkregtelike perspektief. Nederdwitse Gereformeerde Teologiese Tydskrif, 37(1):104-1 14, Maart.

TOFFLER, A. 1990. Powershift: Knowledge, wealth and violence at the edge of the 21 st century. New York : Bantam Books.

TRIMP, C. 1982. Ministerium, een introductie in de reformatorische leer van het ambt Groningen : De Vuurbraak.

VAN DER LINDE, G.P.L. 1983. Die Kerkorde. 'n Verklaring van die gereformeerde kerkorde. Potchefstroom : Potchefstroomse Teologiese Publikasies.

VAN GENDEREN, J. 1996. Orientatie in de dogmageschiedenis. Zoetermeer Boekencentrum.

VAN ITTERZON, G.P. 1974. Het kerkelijk ambt in geding. Kampen : Kok.

VAN OENE, W.W.J. 1990. With common consent. A practical guide to the use of the Church Order of the Canadian Reformed Churches. Winnipeg : Premier Publishing

VAN'T SPIJKER, W. 1988. De ambten bij Martin Bucer. (In Rossouw, P.J., red. Gereformeerde ampsbediening. NG Kerkboekhandel. p. 111-127.)

VELEMA, W.H. 1996. Door het Woord bewogen. Leiden : Groen en Zoon.

VERSTEEG, J.P. 1985. Kijk op de kerk. De structuur van de gemeente volgens het Nieuwe Testament. Kampen : Kok.

VERSTEEG, J.P. 1988. Het karakter van het ambt volgens Efezièrs 4:7-16. (In Rossouw, P.J., red. Gereformeerde ampsbediening. Pretoria : NG Kerkboekhandel. p. 49-74.)

VORSTER, J.M. 1996. Is die kerk funksioneel? Gedagtes oor Gereformeerde kerkvernuwing in 'n postmoderne konteks. Potchefstroom : Potchefstroomse Teologiese Publikasies.

WILLIAMSON, C.M. \& ALLEN, R.J. 1991. The teaching minister. Louisville : Westminster. 
